\title{
Rapid marine biodiversity assessment records 16 new marine fish species for Seychelles, West Indian Ocean
}

\author{
Ryan Daly ${ }^{1 *}$, Guy Stevens ${ }^{1,2}$ and Clare Keating Daly ${ }^{1}$
}

\begin{abstract}
Background: A rapid marine fish biodiversity assessment and subsequent surveys were conducted at D'Arros Island and St. Joseph Atoll, Amirantes, Republic of Seychelles.

Results: Dive surveys recorded the first national occurrence of 16 reef associated fish species. Ten species had regionally cosmopolitan distributions in the West Indian Ocean and their occurrence in Seychelles was expected and confirmed. The occurrence of an additional six species represented range extensions of between approximately 2000 and $4300 \mathrm{~km}$ further than previously reported.

Conclusions: The results of this assessment suggest that the current ichthyofaunal diversity of the Amirantes Island group in the Republic of Seychelles may be underestimated and future surveys are likely to reveal the presence of additional species.
\end{abstract}

Keywords: Rapid marine biodiversity assessment, Marine fish record, West Indian Ocean

\section{Background}

The Economic Exclusion Zone of Seychelles spans $1,374,000 \mathrm{~km}^{2}$ within the West Indian Ocean with a total land mass of $459 \mathrm{~km}^{2}$. There are two primary island regions in Seychelles, the Inner Islands (45 primarily granitic islands in the north including the main Island Mahé) and the Outer Islands which include the Amirantes Island Group. The latter group is comprised of 11 low lying sand cays with a total land area of $11.5 \mathrm{~km}^{2}$ (Stoddart 1984). D'Arros Island and St. Joseph Atoll are situated on the relatively shallow (> $40 \mathrm{~m}$ ) Amirantes Bank, approximately $255 \mathrm{~km}$ southwest of Mahé (Fig. 1). Together, D’Arros Island and St. Joseph Atoll make up $3.03 \mathrm{~km}^{2}$ of low lying land which encompass a variety of marine habitats; including a deep channel separating the islands, platform reefs, an atoll with an extensive lagoon, mangroves and seagrass meadows (primarily Thalassodendron ciliatum) (Stoddart et al. 1979; Stoddart 1984).

The first comprehensive record of the marine fish of Seychelles recorded 775 species from the Inner Islands

\footnotetext{
* Correspondence: ryan@saveourseas.com

'Save Our Seas Foundation - D'Arros Research Centre (SOSF-DRC), Rue

Philippe Plantamour 20, 1201 Genève, Switzerland

Full list of author information is available at the end of the article
}

(Smith and Smith 1969). However, this number was later revised to account for taxonomic confusion and species duplication and Polunin (1984) reported 883 known species from Seychelles waters. Further studies reported an additional 108 species records for Seychelles, some of which were collected and photographed from the Amirante Islands, including 19 species from D'Arros Island and St. Joseph Atoll (Randall and van Egmond 1994). The most recent of these studies highlighted the ichthyofaunal diversity of the region and suggested that further investigation was required to improve our understanding of the diversity and distribution of the marine fish community.

At the beginning of this study there were 1146 marine fish reported from Seychelles including 889 reef associated fish species (Froese and Pauly 2001). The aim of this rapid fish biodiversity assessment was to establish a baseline of the current number of known species from D'Arros Island and St. Joseph Atoll in order to improve monitoring efforts and conservation management plans for the area. 


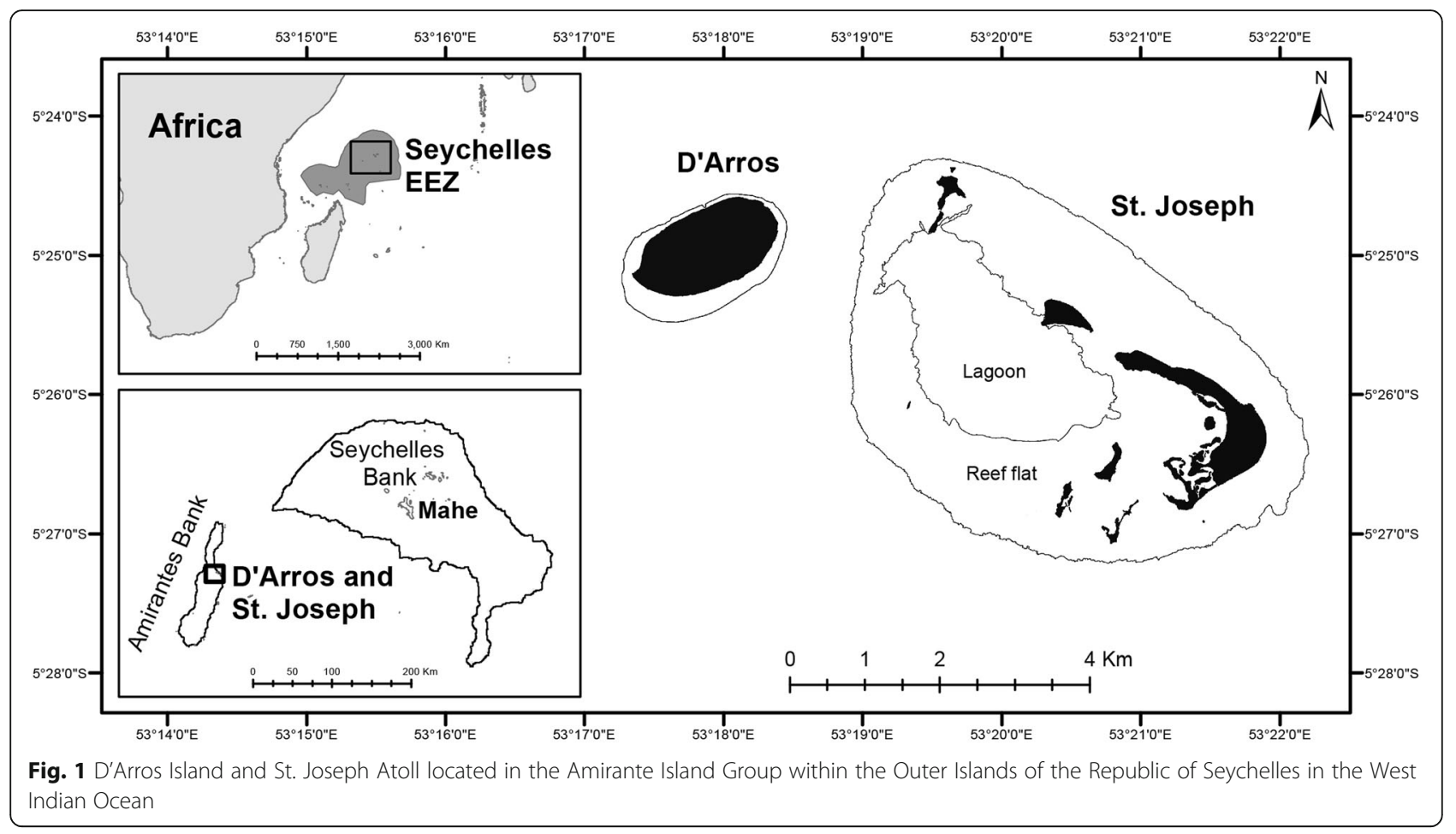

\section{Methods}

Between the 5th and 24th of May 2017, 84 h of underwater visual surveys were conducted around D'Arros Island and St. Joseph Atoll. Additional surveys were then conducted ad-hoc from July 1st to November 2017. During surveys, SCUBA divers recorded and attempted to photograph each new observed fish species. Fish species identification and distributions were confirmed using FishBase (www.fishbase.org), the Global Biodiversity Information Facility (www.gbif.org), the Ocean Biogeographic Information System (www.iobis.org), Fishes of the East Indies (Allen and Erdman 2012) and Fishes of Seychelles (Smith and Smith 1969).

A photographic library of each documented species was also created to serve as a reference point for future studies. All of the major habitat types including deep $(\sim 25 \mathrm{~m})$ and shallow $(\sim 1 \mathrm{~m})$ Thalassodendron meadows, the channel between D'Arros and St Joseph, reef crests, reef slopes (to a maximum of $30 \mathrm{~m}$ ), sand flats (to a maximum of $30 \mathrm{~m}$ ) and atoll lagoon were surveyed.

\section{Results}

A total of 514 marine fish species from 71 families were recorded during the rapid biodiversity assessment at D'Arros Island and St. Joseph Atoll between the 5th and 24th of May 2017. Fifty one percent of the recorded species were represented by eight families: Labridae (66 species), Gobiidae (48 species), Pomacentridae (33 species), Serranidae (30 species), Acanthuridae (26 species), Chaetodontidae (20 species),
Scaridae (20 species) and Carangidae (17 species). During the rapid assessment between the 5th and 24th of May 2017, 12 species previously unreported from Seychelles waters were recorded. An additional 4 new Seychelles species records were subsequently recorded during ad hoc surveys between July 1st and the 19th of November 2017. The 16 previously unreported species from Seychelles represented seven families including: Chaetodontidae, Congridae, Gobiidae, Labridae, Microdesmidae, Syngnathidae and Tetraodontidae. Ten of the new Seychelles species records (Amblygobius nocturnus, Arothron caeruleopunctatus, Dunckerocampus boylei, Gorgasia maculata, Gunnellichthys monostigma, Heniochus diphreutes, Oxycheilinus orientalis, Trimma anaima, Trimma emeryi and Vanderhorstia ambanoro) have relatively cosmopolitan regional distributions and were expected to occur in Seychelles (Figs. 2 and 3). This report serves to confirm their presence in Seychelles waters. The occurrence of the remaining six species (Iniistius naevus, Pseudocoris petila, Pseudojuloides labyrinthus, Trimmatom offucius, Trimma taylori and Trimma winchi) in Seychelles waters represent new range extensions within the Indian Ocean of between 2000 and $4300 \mathrm{~km}$ (Fig. 4). Each species was photographed and notes on their occurrence, characteristics and distribution were recorded.

Amblygobius nocturnus (Herre 1945) (Fig. 2a) was observed and photographed in the lagoon of St. Joseph Atoll $\left(5^{\circ} 25^{\prime} 42.94^{\prime \prime} \mathrm{S} 53^{\circ} 19^{\prime} 26.81^{\prime \prime} \mathrm{E}\right)$ at a depth of $3 \mathrm{~m}$ on the 20th of May 2017. This species is characterised by a pale grey body with a brown to orange stripe running from the snout through the eye and a row of 8-9 dark 

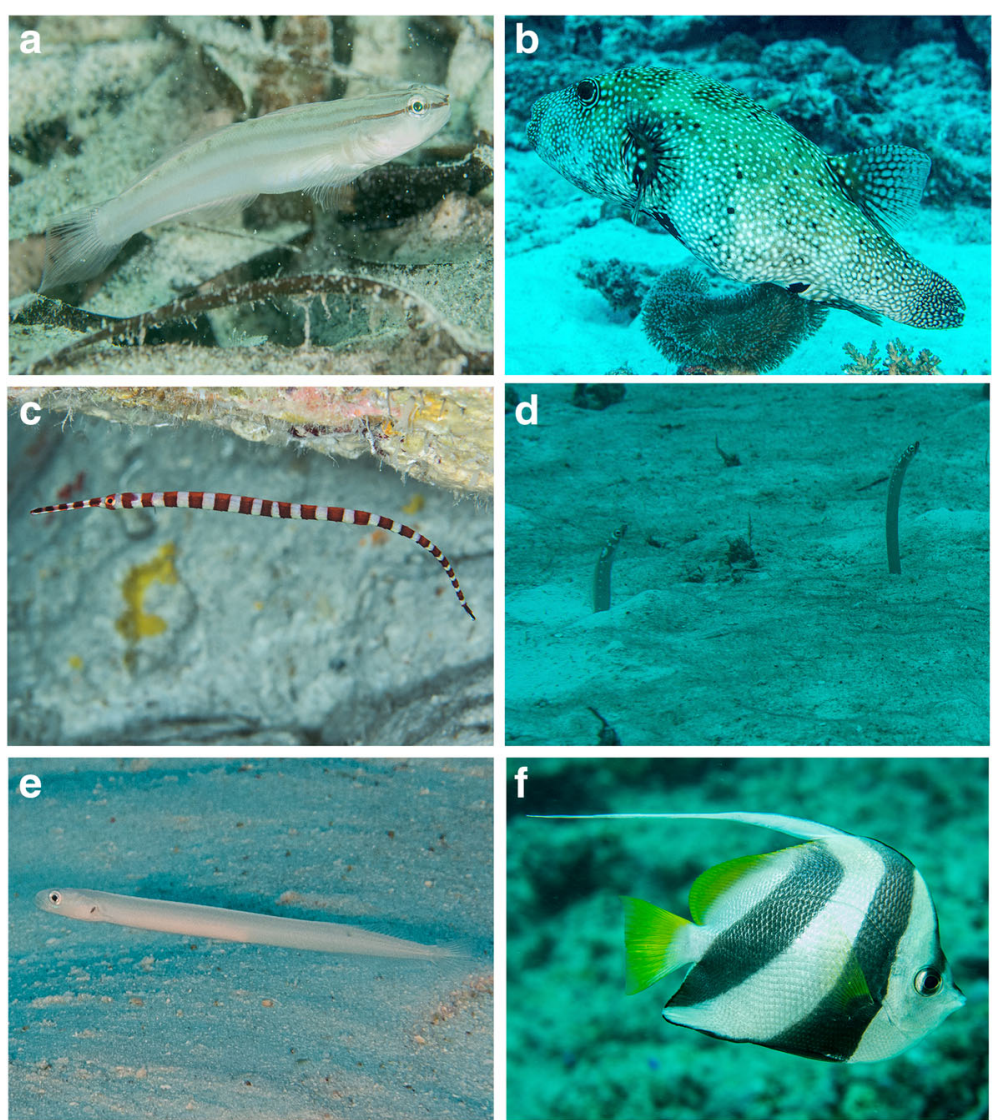

Fig. 2 Marine fish species with regionally cosmopolitan distributions that were recorded for the first time in Seychelles waters. a Amblygobius nocturnus. b Arothron caeruleopunctatus. c Dunckerocampus boylei. d Gorgasia maculata. e Gunnellichthys monostigma. f Heniochus diphreutes
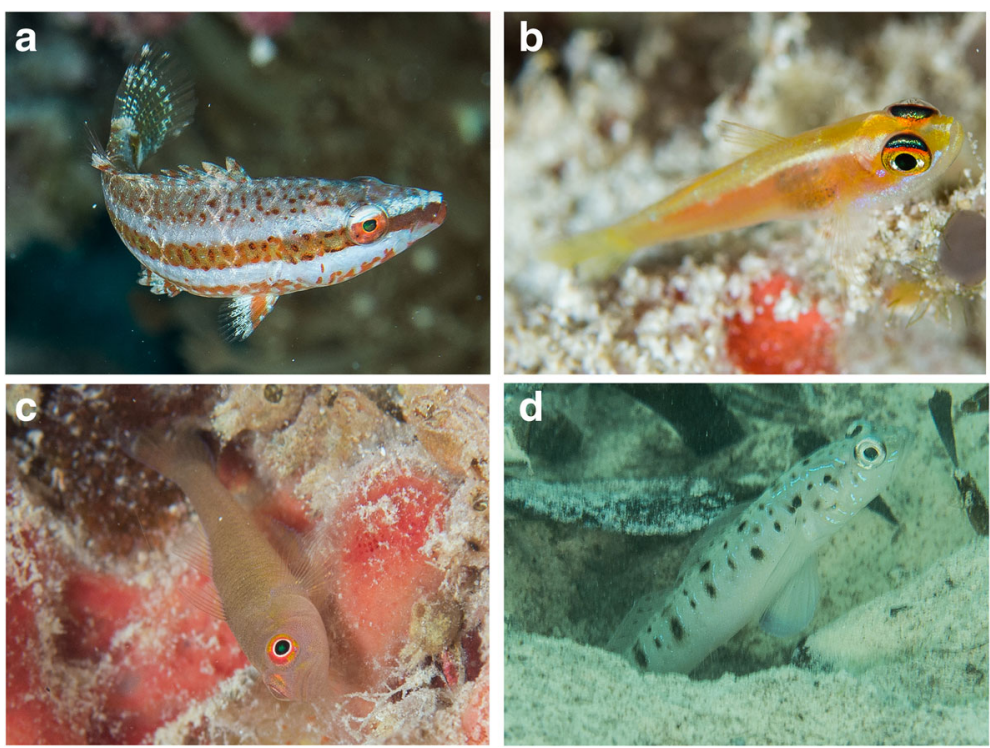

Fig. 3 Marine fish species with regionally cosmopolitan distributions that were recorded for the first time in Seychelles waters. a Oxycheilinus orientalis. b Trimma anaima. c Trimma emeryi. d Vanderhorstia ambanoro 

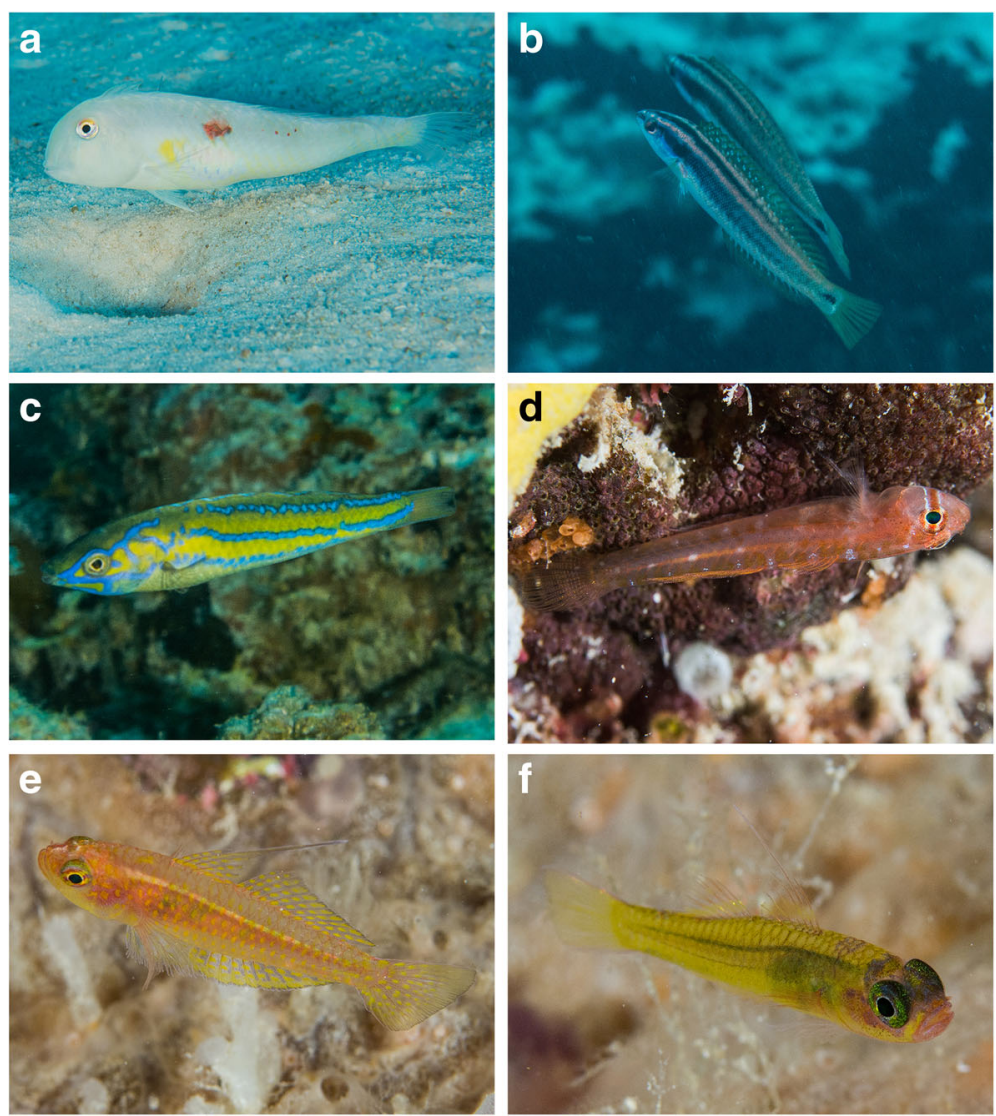

Fig. 4 Marine fish species recorded for the first time in Seychelles waters that represent new range extensions in the Indian Ocean. a Iniistius naevus. b Pseudocoris petila. c Pseudojuloides labyrinthus. d Trimmatom offucius. e Trimma taylori. f Trimma winchi

spots at the base of the dorsal fin (Froese and Pauly 2001, Allen et al. 2003). Distribution ranges from the Red Sea to the Maldives and Mauritius (GBIF) to the Philippines and French Polynesia (Randall 1995; Anderson et al. 1998) and there has been one unpublished report from Seychelles Inner Islands.

Arothron caeruleopunctatus (Matsuura 1994) (Fig. 2b) was observed and photographed north of D'Arros Island $\left(5^{\circ} 24^{\prime} 36.9^{\prime \prime} \mathrm{S} 53^{\circ} 17^{\prime} 49.5^{\prime \prime} \mathrm{E}\right)$ at a depth of $16 \mathrm{~m}$ on the 15th of May 2017. This species is characterised by alternating light and dark rings around the eye, and a black patch with white spots at the base of the pectoral fins (Allen and Erdman 2012). Distribution ranges from Réunion and the Maldives to Indonesia (Froese and Pauly 2001).

Dunckerocampus boylei (Kuiter 1998) (Fig. 2c) was observed and photographed on the west side of St. Joseph Atoll $\left(5^{\circ} 24^{\prime} 46.59^{\prime \prime} \mathrm{S} 53^{\circ} 18^{\prime} 59.21^{\prime \prime} \mathrm{)}\right)$ at a depth of $18 \mathrm{~m}$ on the 22nd of May 2017. This species is characterised by broad red bands and caudal fin with distinct black posterior margin and upper and lower white margins (Kuiter 1998). Known from the Red Sea, South Africa, Mauritius and Indonesia (Allen and Erdman 2012; Kuiter 1998).
Gorgasia maculata (Klausewitz and Eibl-Eibesfeldt 1959) (Fig. 2d) was observed and photographed on the north side of D'Arros Island $\left(5^{\circ} 24^{\prime} 32.55^{\prime \prime} \mathrm{S} 53^{\circ} 17^{\prime} 58.20^{\prime \prime} \mathrm{E}\right)$ at a depth of $26 \mathrm{~m}$ on the 17th of May 2017. This species is characterised by a tan body with the lateral line pores covered in white flecks with larger white blotches on the head (Allen et al. 2003). Distribution ranges from the Comoros Islands and Maldives in the West Indian Ocean to the Solomon Islands in the Pacific (Froese and Pauly 2001, Allen et al. 2003).

Gunnellichthys monostigma (Smith 1958) (Fig. 2e) was observed and photographed off the north side of D'Arros Island ( $\left.5^{\circ} 24^{\prime} 32.55^{\prime \prime} \mathrm{S} 53^{\circ} 17^{\prime} 58.20^{\prime \prime} \mathrm{E}\right)$ at a depth of $26 \mathrm{~m}$ on the 19th of May 2017. This species is characterised by a pale grey body with a distinctive small black spot posteriorly on the opercula and a blue stripe on the head and behind eyes (Allen and Erdman 2012). Distribution ranges from the Red Sea and East Africa to Micronesia and Australia (Allen and Erdman 2012).

Heniochus diphreutes (Jordan 1903) (Fig. 2f) was observed and photographed off the south side of D'Arros Island $\left(5^{\circ} 25^{\prime} 31.19^{\prime \prime} \mathrm{S} 53^{\circ} 17^{\prime} 55.28^{\prime \prime} \mathrm{E}\right)$ on the 6th of May 2017. This species is characterised by a pair of black 
bands across the body with the second band ending at the tip of the anal fin (Allen et al. 2003). This species lacks the distinct black rectangle between eyes and the longer snout of Heniochus acuminatus (Allen et al. 2003). Distribution ranges from the Red Sea and East Africa to Indonesia and Australia (Allen et al. 2003).

Oxycheilinus orientalis (Günther 1862) (Fig. 3a) was observed and photographed off the north side of D'Arros Island on the 12th of May 2017. Males of this species (pictured) are characterised by a mid-lateral red stripe with a pair of spots on the tail (Allen and Erdman 2012). Distribution ranges from the Red Sea and East Africa to Indonesia (Froese and Pauly 2001).

Trimma anaima (Winterbottom 2000) (Fig. 3b) was observed and photographed off the west side of St. Joseph Atoll $\left(5^{\circ} 24^{\prime} 46.59^{\prime \prime} \mathrm{S} 53^{\circ} 18^{\prime} 59.21^{\prime \prime} \mathrm{E}\right)$ at a depth of $18 \mathrm{~m}$ on the 23rd of May 2017. This species is characterised by a broad red or orange mid lateral stripe, white belly and thin blue lines below eyes (Allen and Erdman 2012). Distribution ranges from the Comoro Islands and Maldives Islands to Indonesia (Allen and Erdman 2012).

Trimma emeryi (Winterbottom 1985) (Fig. 3c) was observed and photographed on the east side of D'Arros Island at a depth of $20 \mathrm{~m}$ on the 8th of October 2017. Characterised by red iris and a yellow to pink head and a translucent pale yellow body (Allen and Erdman 2012). Distribution ranges from the Comoro Islands and Maldives to Chagos and Indonesia, Guam and Tonga (Allen and Erdman 2012).

Vanderhorstia ambanoro (Fourmanoir 1957) (Fig. 3d) was observed and photographed in the lagoon of St. Joseph Atoll $\left(5^{\circ} 25^{\prime} 42^{\prime \prime} \mathrm{S} 53^{\circ} 19^{\prime} 26^{\prime \prime} \mathrm{E}\right)$ on the 20th of May 2017. This species is characterised by a pale grey to white body with large black spots laterally and smaller dorsal spots and blue streaks on head and dorsal surface (Allen and Erdman 2012). Distribution ranges from the Red Sea, Madagascar and East Africa to Micronesia and Samoa (Allen and Erdman 2012).

Iniistius naevus (Allen and Erdman 2012) (Fig. 4a) was observed and photographed off the north side of D'Arros Island ( $\left.5^{\circ} 24^{\prime} 33.16^{\prime \prime} \mathrm{S} 53^{\circ} 17^{\prime} 57.77^{\prime \prime} \mathrm{E}\right)$ at a depth of $24 \mathrm{~m}$ on the 18th of May 2017. This species is characterised by a white belly patch with a dark red blotch above it and a similar size yellow blotch anterior to it (Allen and Erdman 2012). Previously only known from the Andaman Islands (Allen and Erdman 2012). This record extends the known range by approximately $4300 \mathrm{~km}$ and confirms its occurrence in the West Indian Ocean.

Pseudocoris petila (Allen and Erdman 2012) (Fig. 4b) was observed and photographed off the western side of St. Joseph Atoll $\left(5^{\circ} 24^{\prime} 46.59^{\prime \prime} \mathrm{S} 53^{\circ} 18^{\prime} 59.21^{\prime \prime} \mathrm{E}\right)$ at a depth of $12 \mathrm{~m}$ on the 22nd of May 2017. This species is characterised by a distinctive purple cheek and elongate body. Previously only known from the Andaman Islands
(Froese and Pauly 2001, GBIF), $4300 \mathrm{~km}$ to the east. However, there have been more recent unconfirmed reports from South Africa, Réunion Island and Pulau Weh (Allen and Erdman 2012).

Pseudojuloides labyrinthus (Victor and Edward 2016) (Fig. 4c) was observed and photographed on the northern side of D'Arros Island ( $\left.5^{\circ} 24^{\prime} 33.16^{\prime \prime} \mathrm{S} 53^{\circ} 17^{\prime} 57.77^{\prime \prime} \mathrm{E}\right)$ at a depth of $26 \mathrm{~m}$ on the 19th of November 2017. The terminal male (photographed) is characterised by a maze of blue lines on the head and three blue stripes along the body. Only previously known from the aquarium trade in Kenya approximately $2000 \mathrm{~km}$ west of Seychelles (Victor and Edward 2016).

Trimmatom offucius (Winterbottom and Emery 1981) (Fig. 4d) was observed and photographed off the west side of St. Joseph Atoll ( $\left.5^{\circ} 24^{\prime} 46.59^{\prime \prime} \mathrm{S} 53^{\circ} 18^{\prime} 59.21^{\prime \prime} \mathrm{E}\right)$ at a depth of $18 \mathrm{~m}$ on the 15th of September 2017, after the rapid biodiversity assessment was completed. This species is characterised by an orange-red bar about the diameter of the eye across the cheek below the eye (Winterbottom and Emery 1981). Known previously from Chagos Archipelago (Winterbottom and Emery 1981). This record extends its known range by approximately $2000 \mathrm{~km}$ further westward and confirms its occurrence in the Southwest Indian Ocean.

Trimma taylori (Lobel 1979) (Fig. 4e) was observed and photographed off the west side of St. Joseph Atoll $\left(5^{\circ} 24^{\prime} 46.59^{\prime \prime} \mathrm{S} 53^{\circ} 18^{\prime} 59.21^{\prime \prime} \mathrm{E}\right)$ at a depth of $18 \mathrm{~m}$ on the 23rd of May 2017. Subsequent photographs of the specimen shown here were taken at the same location on the 16th of September 2017. This species is characterised by elongate second dorsal spine, semi-translucent upper body and yellow to orange spots on the head and median fins (Allen and Erdman 2012; Froese and Pauly 2001; Winterbottom 1984). Distribution ranges throughout the East Indies and is also known from the Red Sea and Chagos Archipelago in the central Indian Ocean (Allen and Erdman 2012; Froese and Pauly 2001). This record extends the known range by approximately $2000 \mathrm{~km}$ west of Chagos and confirms its occurrence in the Southwest Indian Ocean.

Trimma winchi (Winterbottom 1984) (Fig. 4f) was observed and photographed off the west side of St. Joseph Atoll $\left(5^{\circ} 24^{\prime} 46.59^{\prime \prime} \mathrm{S} 53^{\circ} 18^{\prime} 59.21^{\prime \prime} \mathrm{E}\right)$ at a depth of $18 \mathrm{~m}$ on the 23rd of May 2017. Subsequent photographs of the specimen shown here were taken at the same location on the 16th of September 2017. This species is characterised by a yellow body, pink jaws, black melanophores along mid-lateral line and elongated second dorsal spine reaching posteriorly slightly beyond the base of the last dorsal fin ray (Winterbottom 1984). Known previously from Chagos Archipelago (Winterbottom 1984; Froese and Pauly 2001). This record extends the known range of the species by approximately $2000 \mathrm{~km}$ further 
westward and confirms its occurrence in the Southwest Indian Ocean.

\section{Discussion}

New marine fish records from Seychelles after Smith and Smith (1969) comprehensive account were last reported by Randall and van Egmond (1994), who recorded 108 new species nationally. At least 35 of these species were found within the Amirantes Island group, highlighting the potentially rich fish diversity associated with the area (Randall and van Egmond 1994). The previously unreported Seychelles records found in this study appear to be in part due to the lack of previous survey effort in the region owing to the relative remoteness of the Islands. Indeed, 10 out of the 16 newly recorded fish species in this study have regionally cosmopolitan distributions and their occurrence was expected. The remaining six species reported in this study were most likely previously overlooked as they are relatively small and cryptic (in the case of the Gobiidae; Trimmatom offucius, Trimma taylori and Trimma winchi) or were only recently described (Iniistius naevus, Pseudocoris petila and Pseudojuloides labyrinthus).

Of particular interest are the new Seychelles records of species only know from the east and central Indian Ocean (Chagos Islands). The presence of these species (Trimmatom offucius, Trimma taylori and Trimma winchi) suggests that they dispersed westward across the Indian Ocean supporting evidence from (Craig 2008) who suggested westward dispersal in the region may be possible during the north west monsoon (November to March). Indeed, Chagos may be an important "stepping stone" for the dispersal of fishes from the relatively species rich Indo-Pacific region to the west Indian Ocean. Additional biodiversity surveys in Seychelles may well reveal the presence of more central and east Indian Ocean fishes.

Previous studies in Seychelles employing similar diver survey methods to this study recorded between 221 and 369 marine fish species (Downing et al. 2006, Friedlander et al. 2015). However, it is likely that targeted searches for more cryptic or recently described species in Seychelles would yield many more species records. Within the broader West Indian Ocean, diver based surveys have recorded between 217 and 394 coastal marine fish species (Garpe and Öhman 2003, Durville et al. 2003, Chabanet et al. 2002, Letourneur et al. 2004, Gillibrand et al. 2007, Fricke et al. 2013) although more comprehensive check lists within the region have recorded up to 984 species (Fricke et al. 2009, Wickel et al. 2014). Considering the relatively limited spatial and temporal scales of the survey reported on in this study, the number of fish species recorded appears to be representative of an exceptionally diverse marine fish community. The diversity is most likely facilitated by the various marine habitat types (seagrass, lagoon, coral reef and rubble reef) within a relatively confined area at D'Arros Island and St. Joseph Atoll.

\section{Conclusion}

The 514 marine fish species recorded during the rapid marine biodiversity assessment between the 5th and 25th of May 2017 (as well as the four species recorded during additional surveys) highlights the unique ichthyofaunal biodiversity of D'Arros and St. Joseph Islands in the Amirante Island Group, Seychelles. It is likely that previous records from the region have under represented the marine fish community due to a lack of targeted surveys, especially in deeper and sand/rubble dominated habitats. Misidentification resulting in synonymised species may also have contributed to the under representation of species diversity records. Thus, it is likely that with additional survey effort more, potentially undescribed, species from the region will be added to the national record of fishes from Seychelles waters. Considering the unique ichthyofaunal diversity of the region it is important to ensure the equally diverse marine habitats of areas such as D'Arros and St. Joseph are conserved. Improved conservation measures are especially important in light of increasing impacts from coral reef bleaching events, which resulted in substantial hard coral reef die off in the region in 2016 (Obura et al. 2017).

\section{Acknowledgements with fish species identification was gladly provided by Dr. Rick \\ Winterbottom, Dr. David Greenfield, Dr. Mark Erdman, Dr. Jack Randall, Dr. Gerry Allen and Dr. Benjamin Victor, this report would not have been possible without their help. \\ Funding \\ This study was supported by the Save Our Seas Foundation.}

Many thanks to Justin Blake for participating in the diver surveys. Assistance

\section{Availability of data and materials}

All data generated or analysed during this study are included in this published report. All photographic records used in this report have also been added to the fish photographic identification data base at the D'Arros Research Centre, Amirantes, Seychelles.

\section{Authors' contributions}

RD conducted the diving surveys, photographed specimens and contributed to the manuscript. GS conducted the diving surveys, photographed specimens and contributed to the manuscript. CKD contributed to the writing and editing of the manuscript. All authors read and approved the final manuscript.

Ethics approval

There were no required ethical considerations.

\section{Consent for publication}

No consent was required.

Competing interests

All authors declare that they have no competing interests.

\section{Publisher's Note}

Springer Nature remains neutral with regard to jurisdictional claims in published maps and institutional affiliations. 


\section{Author details}

'Save Our Seas Foundation - D'Arros Research Centre (SOSF-DRC), Rue Philippe Plantamour 20, 1201 Genève, Switzerland. ${ }^{2}$ The Manta Trust, Catemwood House, Corscombe, Norwood Lane, Dorset DT2 ONT, UK.

\section{Received: 23 January 2018 Accepted: 26 March 2018}

\section{Published online: 12 April 2018}

\section{References}

Allen GR, Steene RC, Humann P, DeLoach N. Reef fish identification: Tropical Pacific. Jacksonville: New World Publications; 2003.

Allen GR, Erdman MV. Reef fishes of the East Indies. Volumes I-III. Perth: Tropical Reef Research; 2012.

Anderson RC, Randall JE, Kuiter RH. New records of fishes from the Maldive Islands, with notes on other species. Ichthyol Bull. 1998;67:20-36.

Chabanet $P$, Tessier E, Durville P, Mulochau T, René F. Peuplement ichtyologique des bancs de Geyser et Zélée (Océan Indien Occidental). Cybium. 2002;26:11-26.

Craig MT. The Goldrim surgeonfish (Acanthurus nigricans; Acanthuridae) from Diego Garcia, Chagos archipelago: first record for the Central Indian Ocean. Zootaxa. 2008;1850:65-8.

Downing N, Stobart B, Buckley R, Teleki K. Recovery of coral and fish following the 1998 El Nino event at Aldabra atoll, southern Seychelles: a site with minimal anthropogenic influence. In: Proceedings of the 10th international coral reef symposium. Okinawa: International Society for Reef Studies; 2006. p. $664-75$.

Durville P, Chabanet P, Quod JP. Visual census of the reef fishes in the natural reserve of the Glorieuses Islands (western Indian Ocean). West Ind Ocean Jo Mar Sci. 2003:95-104

Fourmanoir P. Poissons Téléostéens des eaux malgaches du canal de Mozambique. Mémoires de l'Institut Scientifique de Madagascar. Océanographie. 1957;1:1-316.

Fricke R, Durville P, Bernadi G, Borsa P, Moutham G, Chabenet P. Checklist of the shore fishes of Europa Island, Mozambique channel, southwestern Indian Ocean, including 302 new records. Stuttg Beitr Naturkd. 2013;6:247-76.

Fricke R, Mulochau T, Durville P, Chabenet P, Tessier E, Letourneur Y. Annotated check list of the species (Pisces) of La Réunion, including a red list of threatened and declining species. Stuttg Beitr Naturkd. 2009:2:1-168.

Friedlander AM, Ballesteros E, Beets J, Brown EK, Fay JM, Haupt P, Henning B, Rose P, Sala E. Biodiversity and ecosystem health of the Aldabra group, southern Seychelles: scientific report to the government of Seychelles. Natl Geogr Pristine Seas. 2015;1-60.

Froese R, Pauly D. Fishbase. World Wide Web electronic publication. 2001. www.fishbase.org. Accessed 15 Mar 2018

Garpe KC, Öhman MC. Coral and fish distribution patterns in Mafia Island Marine Park, Tanzania: fish-habitat interactions. Hydrobiologia. 2003;498:191-211.

Gillibrand CJ, Harris AR, Mara E. Inventory and spatial assemblage study of reef fish in the area of Andavadoaka, south-West Madagascar (western Indian Ocean). West Ind Ocean J Mar Sci. 2007:6:183-97.

Global Biodiversity Information Facility. www.gbif.org. Accessed 15 Mar 2018.

Günther A. Catalogue of the fishes in the British museum. Catalogue of the Acanthopterygii, Pharyngognathi and Anacanthini in the collection of the British museum. Br Mus. 1862:4:1-534.

Herre AWCT. Notes on fishes in the zoological Museum of Stanford University. XII. Two new genera and four new gobies from the Philipines and India. Copeia. 1945;1:1-6.

Jordan DS. Supplementary note on Bleekeria mitsukurii, and on certain Japanese fishes. Proc U S Natl Mus. 1903;26:693-6.

Klausewitz W, Eibl-Eibesfeldt I. Neue Röhrenaale von den Maldiven und Nikobaren (Pisces, Apodes, Heterocongridae). Senckenberg Biol. 1959;40:135-53.

Kuiter RH. Pipefishes of the syngnathid genus Dunckerocampus (Sygnathiformes: Sygnathidae), with a description of a new species from the Indian Ocean Aqua J Ichthyol Aquat Biol. 1998;3:81-4.

Letourneur Y, Chabanet P, Durville P, Taquet M, Teissier E, Parmentier M, Quero J, Pothin K. An updated checklist of the marine fish fauna of Réunion Island, South-Western Indian Ocean. Cybium. 2004;28:199-216.

Lobel PS. Description of a new Hawaiian gobiid fish of the genus Trimma. Breviora. 1979;456:1-15.

Matsuura K. Arothron caeruleopunctatus, a new puffer from the indo-western Pacific. Jap J Ichthyol. 1994;4:29-33.

Obura D, Gudka M, Abdou Rabi, F, Bacha Gian, S, Bijoux J, Freed, S, Maharavo, J, Mwaura J, Porter S, Sola E, Wickel J, Yahya S, Ahamada S. Coral reef status report for the western Indian Ocean. In: global coral reef monitoring network (GCRMN)/international coral reef initiative (ICRI). CORDIO East Africa. 2017. http://cordioea.net/gcrmnwio2017. Accessed 13 Mar 2018.

Ocean Biogeographic Information System. www.iobis.org. Accessed 15 Mar 2018

Polunin NVC. Marine fishes of the Seychelles. In: Stoddart DR, editor. Biogeography and ecology of the Seychelles. Massachusetts: Kluwer Boston; 1984. p. 171-91.

Randall JE. Coastal fishes of Oman. Honolulu: University of Hawaii Press; 1995.

Randall JE, van Egmond J. Marine fishes from the Seychelles: 108 new records. In: van der Land J, editor. Results of the 'oceanic reefs' expedition to the Seychelles (1992-1993). Leiden: Academic; 1994. p. 43-83.

Smith JLB. The gunnellichthid fishes with description of two new species from East Africa and of Gunnellichthys (Clarkichthys) bilineatus (Clark), 1936. Ichthyological Bulletin, Department of Ichthyology, Rhodes University. 1958;9: $123-9$

Smith JLB, Smith MM. The fishes of Seychelles. Cape Town: Transvaal Printers; 1969.

Stoddart DR. Biogeography and ecology of the Seychelles. Massachusetts: Kluwer Boston; 1984. p. 691.

Stoddart DR, Coe MJ, Fosberg FR. D'Arros and St. Joseph, Amirante Islands. Atoll Res Bull. 1979:223:1-48.

Victor CV, Edward JMB. Pseudojuloides labyrinthus, a new labrid fish (Teleostei: Labridae) from the western Indian Ocean. J Ocean Sc Found. 2016:21:58-70.

Wickel J, Jamon A, Pinault M, Chabanet P. Species composition and structure of marine fish communities in Mayotte Island (south-western Indian Ocean). Cybium. 2014;38:179-203.

Winterbottom R. A review of the gobiid fish genus Trimma from the Chagos archipelago, Central Indian Ocean, with the description of seven new species. Can J Zool. 1984;62:695-715.

Winterbottom R. Two new gobiid fish species (in Priolepis and Trimma) from the Chagos archipelago, Central Indian Ocean. Can J Zool. 1985;63:748-54.

Winterbottom R. Four new species of Trimma (Gobiidae), from the Indian and western Pacific oceans. J Ichthyol Aquat Biol. 2000;4:57-66.

Winterbottom R, Emery AR. A new genus and two new species of gobiid fishes (Perciformes) from the Chagos archipelago. Central Indian Ocean Environ Biol Fish. 1981:6:139-49.

\section{Submit your next manuscript to BioMed Central and we will help you at every step:}

- We accept pre-submission inquiries

- Our selector tool helps you to find the most relevant journal

- We provide round the clock customer support

- Convenient online submission

- Thorough peer review

- Inclusion in PubMed and all major indexing services

- Maximum visibility for your research

Submit your manuscript at www.biomedcentral.com/submit
) Biomed Central 